\title{
Computerized tomography (the EMI Scanner): a comparison with pneumoencephalography and ventriculography
}

\author{
J. GAWler, G. H. DU BOUlAy, J. W. D. BULL, AND J. MARShALL \\ From The National Hospital for Nervous Diseases, Queen Square, London
}

SYNOPSIS Computerized tomography, using the EMI Scanner, allows the diagnosis of cerebral atrophy or hydrocephalus to be made with the same degree of accuracy as conventional neuroradiological methods. Ventricular measurements made on EMI scans have been compared with those from pneumoencephalograms and ventriculograms. A range of normal ventricular measurements for the EMI scan is suggested.

Because the small difference in tissue density between cerebrospinal fluid and brain tissue is resolved by computerized tomography the ventricular system, subarachnoid cisterns, and cortical sulci can be visualized without recourse to contrast media. Focal or generalized ventricular enlargement is readily seen and widening of cortical or cerebellar sulci can be detected. Obstructive hydrocephalus can generally be distinguished from cerebral atrophy and angiography or pneumoencephalography are often avoided.

One problem which attends the introduction of new diagnostic equipment is to establish the normal. Before the EMI Scanner became available, encephalography or ventriculography were the only means of demonstrating the ventricular system and subarachnoid space clearly during life. It is thus of value to compare the EMI scan with a conventional ventricular contrast procedure when both are undertaken in the same patient, for nearly 60 years of experience has accumulated in relation to the latter method.

\section{METHODS}

We have reviewed 80 by 80 matrix EMI scans and conventional ventricular contrast procedures from patients investigated by both. As ventricular size and the appearance of the subarachnoid space were to be compared, those with mass lesions involving the cerebral hemispheres were excluded.

Comparison was made between the EMI scan and either a pneumoencephalogram or pneumoventriculogram in 78 patients whose ages ranged from 8 months to 73 years. EMI scanning had always been undertaken before the ventricular contrast procedure but the investigations were never separated by more than 21 days. Seventy-five percent of the contrast procedures had been undertaken during general anaesthesia.

Our original intention was to correlate EMI scans and pneumoencephalograms, in a prospective manner, among patients with dementia referred for both investigations. It soon became clear, however, that computerized scans reliably demonstrated cerebral atrophy and subsequent contrast investigations were not justified. The initial EMI system, using the 80 by 80 matrix picture, was improved by a high resolution 160 by 160 matrix scan which provided a clearer image of the intracranial anatomy (Fig. 1). As a result, the number of pneumoencephalograms undertaken each month at The National Hospital has fallen from 50 to less than 10 since the EMI Scanner became available and it is now hard to find contrast studies which are normal or show only atrophy to correlate with high resolution EMI scans. All the 80 by 80 matrix examinations with comparable ventricular contrast procedures were therefore studied to ascertain the reliability of scanning and to establish normal limits for the technique.

EVALUATION OF COMPUTERIZED TOMOGRAMS The intracranial content is displayed by a contiguous 


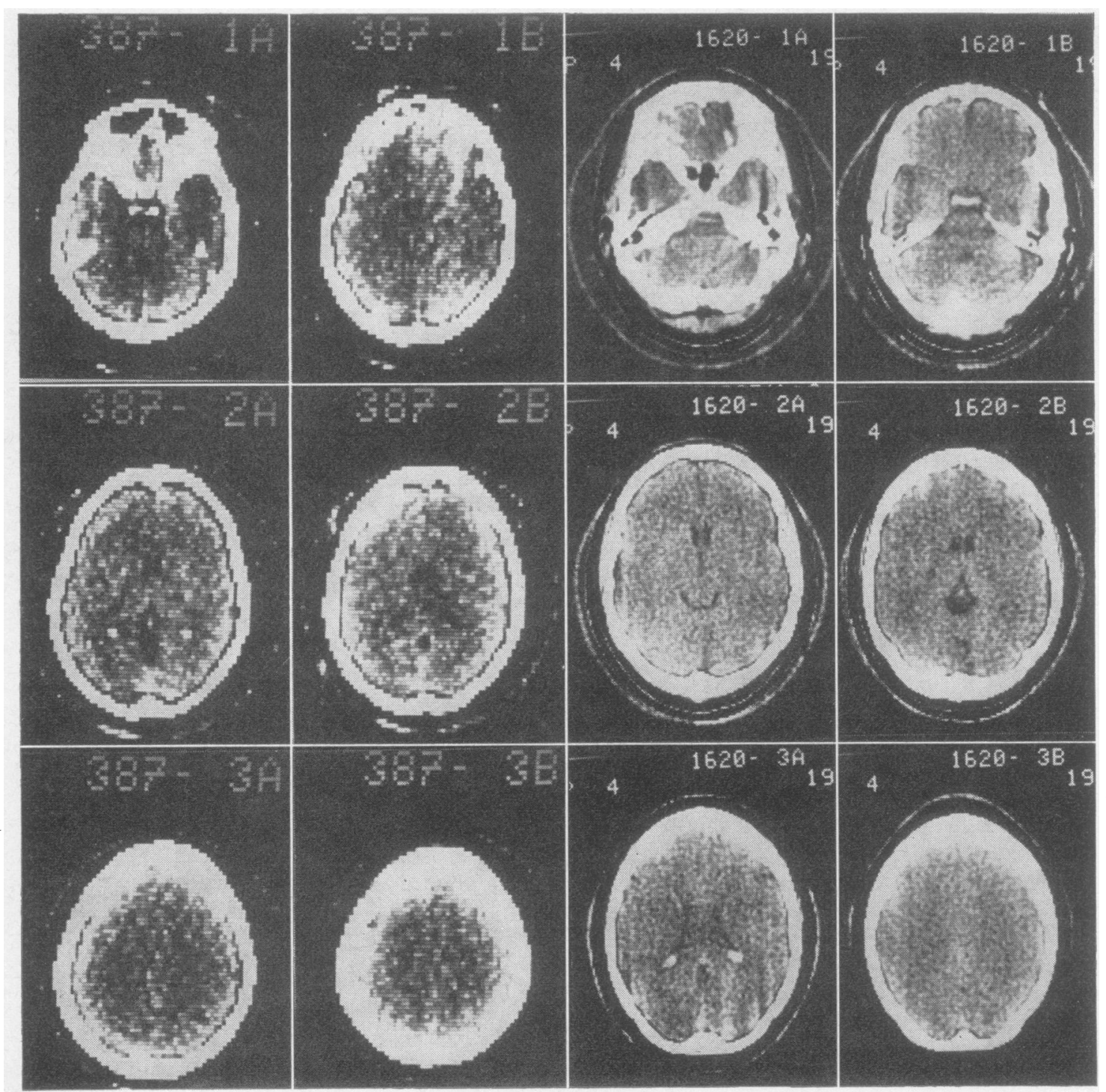

(a)

(b)

FIG. 1 (a) Normal 80 by 80 matrix EMI scan. (b) Normal 160 by 160 matrix EMI scan. Comparison of these examinations demonstrates the greater clarity with which the ventricular system and subarachnoid space are seen on the high resolution scan.

series of six or eight transverse tomograms. Each tomogram represents those structures within a transverse 'slice' of the head $13 \mathrm{~mm}$ in depth. The vertical dimension of an individual 'slice' is lost by superimposition but a three-dimensional impression is obtained from the series. An 80 by 80 matrix tomogram is composed of 6400 cells each measuring $3 \mathrm{~mm}$ by $3 \mathrm{~mm}$ in the transverse plane and having a depth of $13 \mathrm{~mm}$. The $x$-ray absorption coefficient registered at each cell represents the average absorption from all the tissues within it. Cells containing only cerebrospinal fluid have a value of 0 or 1 , while those encompassing only cerebral tissue give values between 11 and 30 . At the ventricular margin cells will contain both fluid and brain tissue and a numerical gradient is likely here (Fig. 2). 


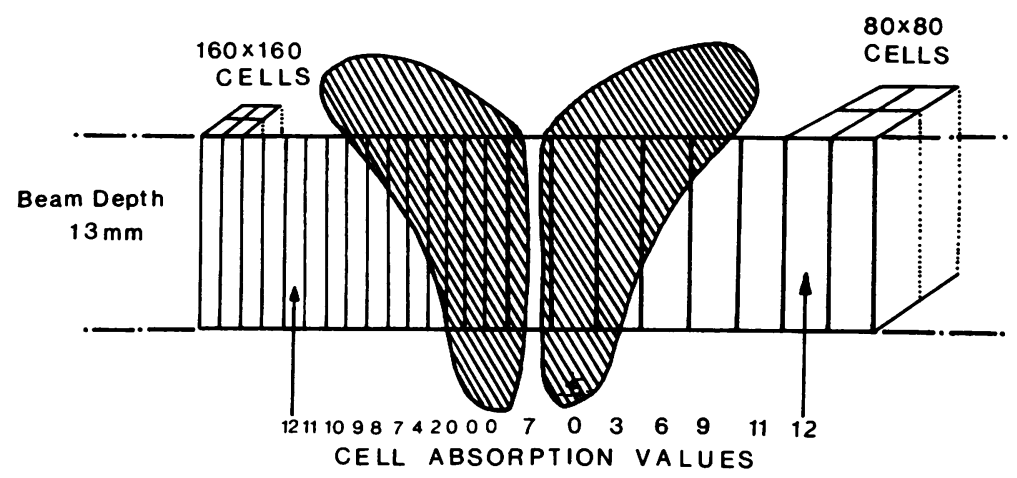

FIG. 2 Computerized tomograms represent a tissue 'slice' $13 \mathrm{~mm}$ in depth so that the ventricular margins occupy several cells. A numerical gradient of x-ray absorption values therefore exists at the ventricular perimeter.
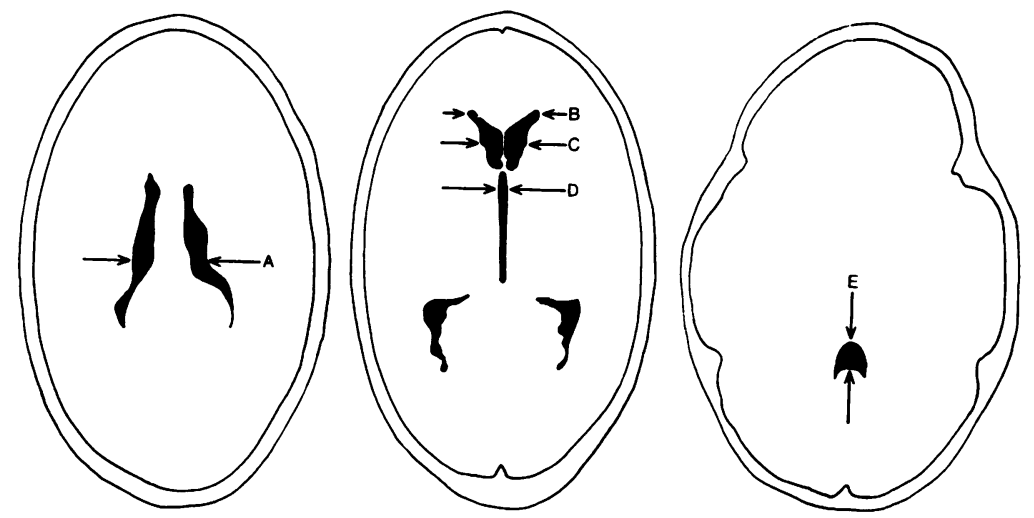

FIG. 3 Ventricular measurements taken from computerized scans. For description see text.
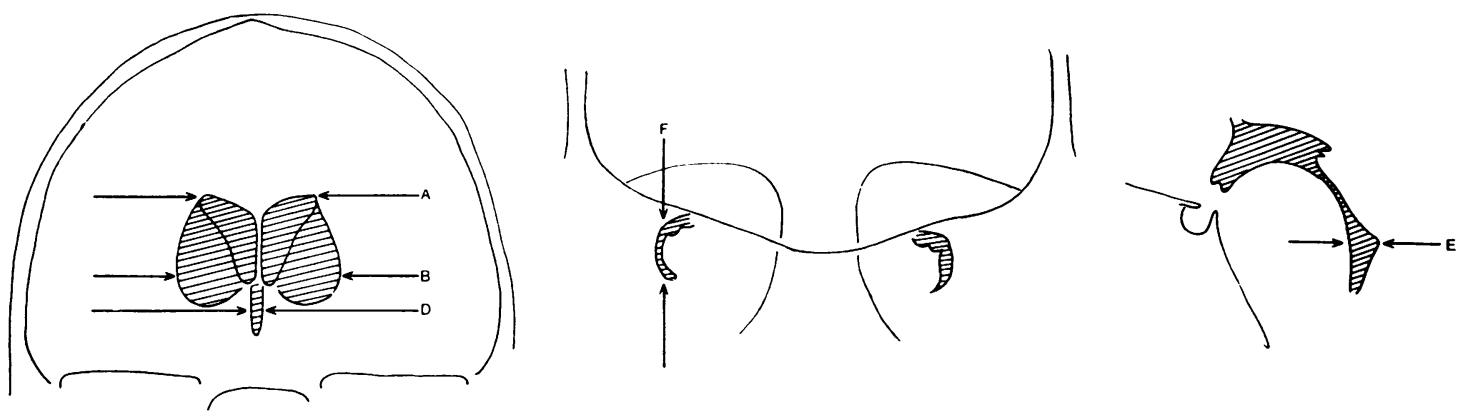

FIG. 4 Ventricular measurements taken from conventional ventricular contrast procedures. For description see text. 
When the ventricular extremity lies within cells that contain principally cerebral tissue a reduction in density may not be apparent and the ventricle would then appear smaller than its true size. Conversely, when a cell contains sufficient fluid to lower its density the whole cell is registered as ventricle, even when only a segment of ventricle projects into it. This would increase apparent ventricular size.

Appropriately adjusted, the oscilloscope display will show the ventricular margins fairly well, but as the display can be varied in size and the focal length of the Polaroid camera altered, absolute measurements are best taken from the numerical printout of absorption values. Cells having a value less than 11 were considered to contain cerebrospinal fluid and the ventricular margins have been constructed on this basis.

All measurements given in this communication have been obtained by counting $3 \mathrm{~mm}$ by $3 \mathrm{~mm}$ cells on the numerical printout and the following have been obtained from each EMI scan (Fig. 3).

A. The greatest width between the lateral aspects of the cellae mediae. (The lateral ventricles diverge posteriorly, especially as the cellae mediae approach the trigones. Care was therefore taken to restrict this measurement to the cellae mediae and not to include the superior aspects of the trigones.)

B. The width between the lateral extremities of the tips of the frontal horns.

C. The distance between the lateral aspects of the frontal horns measured halfway along their anteroposterior length.

D. The maximum width of the third ventricle.

E. The anteroposterior extent of the fourth ventricle measured in the midline.

The ratio described by Evans (1942), the distance between the tips of the frontal horns divided by the width of the skull measured between its inner tables, was calculated for each patient. Scans were scrutinized for evidence of cerebral or cerebellar atrophy and a record made of widened sulci, enlargement of the interhemispheric fissure, or dilatation of the insular cisterns. All the EMI scans were evaluated without reference to the contrast procedures by one observer (J.G.) and a conclusion-normal, atrophy (cerebral or cerebellar), or hydrocephalus-was reached.

EVALUATION OF CONVENTIONAL STUDIES A second observer (G.H. du B) reviewed all the ventricular contrast procedures without knowledge of the EMI scan findings and the following measurements were taken (Fig. 4).

A. The width of the cellae mediae measured across the superior aspects of the lateral ventricles.
B. The distance between the lateral extremities of the tips of the frontal horns.

D. The maximum width of the third ventricle.

E. The greatest distance between the roof and floor of the fourth ventricle.

F. The height of the lateral cleft of the larger temporal horn.

Evans's ratio was calculated from the contrast procedure and evidence of cerebral or cerebellar atrophy noted. The width of the largest cortical sulcus was recorded and those $4 \mathrm{~mm}$ or more in width were regarded as abnormal.

Using the criteria set out by Engeset and Skraastad (1964) in their review of ventricular measurements, a conclusion about each radiological procedure was reached in the manner described for the EMI scan.

\section{RESULTS}

In 59 of the 78 patients in this series the conclusions drawn from both methods of investigation were identical (Table 1). In the remaining 19 the findings differed (Table 2) and will be described in detail. Seven pneumoencephalograms proved incomplete; four showed no ventricular filling, and three had one lateral ventricle unfilled. The high incidence of technically unsuccessful contrast procedures reflects the referral of such patients for EMI scans to exclude a structural

\section{TABLE 1}

COMPARISON OF EMI SCAN AND VENTRICULAR CONTRAST PROCEDURE (78 PATIENTS)

\begin{tabular}{lcc}
\hline $\begin{array}{l}\text { Full agreement between techniques } \\
\text { (59 patients) }\end{array}$ & $\begin{array}{c}\text { No. } \\
\text { Total } \\
\text { no. }\end{array}$ \\
\hline $\begin{array}{l}\text { Cerebral atrophy } \\
\text { a. Ventricles and sulci enlarged } \\
\text { b. Sulci only enlarged } \\
\text { c. Ventricles enlarged, sulci equivocal }\end{array}$ & 20 & \\
\hline Total & 3 & \\
\hline $\begin{array}{l}\text { Borderline cerebral atrophy } \\
\text { a. Ventricles and sulci equivocal }\end{array}$ & 27 & 27 \\
\hline b. Sulci equivocal & 2 & \\
\hline $\begin{array}{l}\text { Total } \\
\text { Hydrocephalus }\end{array}$ & 3 & 5 \\
\hline $\begin{array}{l}\text { Normal } \\
\text { Normal ventricular system but posterior } \\
\text { fossa tumour }\end{array}$ & 12 \\
\hline $\begin{array}{l}\text { Postoperative cavity and generalized } \\
\text { cerebral atrophy }\end{array}$ & 11 \\
\hline \begin{tabular}{l} 
Total \\
\hline
\end{tabular} & 59 \\
\hline
\end{tabular}


cause for nonfilling. In this group no cause was found, five EMI scans being normal and two showing cerebral atrophy.

Two patients had normal ventricular dimensions on both the computerized scan and contrast study but the latter showed distension of the anterior recesses of the third ventricle (ballooning). One of these patients had cerebellar ectopia and the other a small acoustic neuroma. Four EMI scans were normal when the pneumoencephalogram showed either slight lateral ventricular enlargement or equivocal sulcal widening. Six patients showed enlargement of

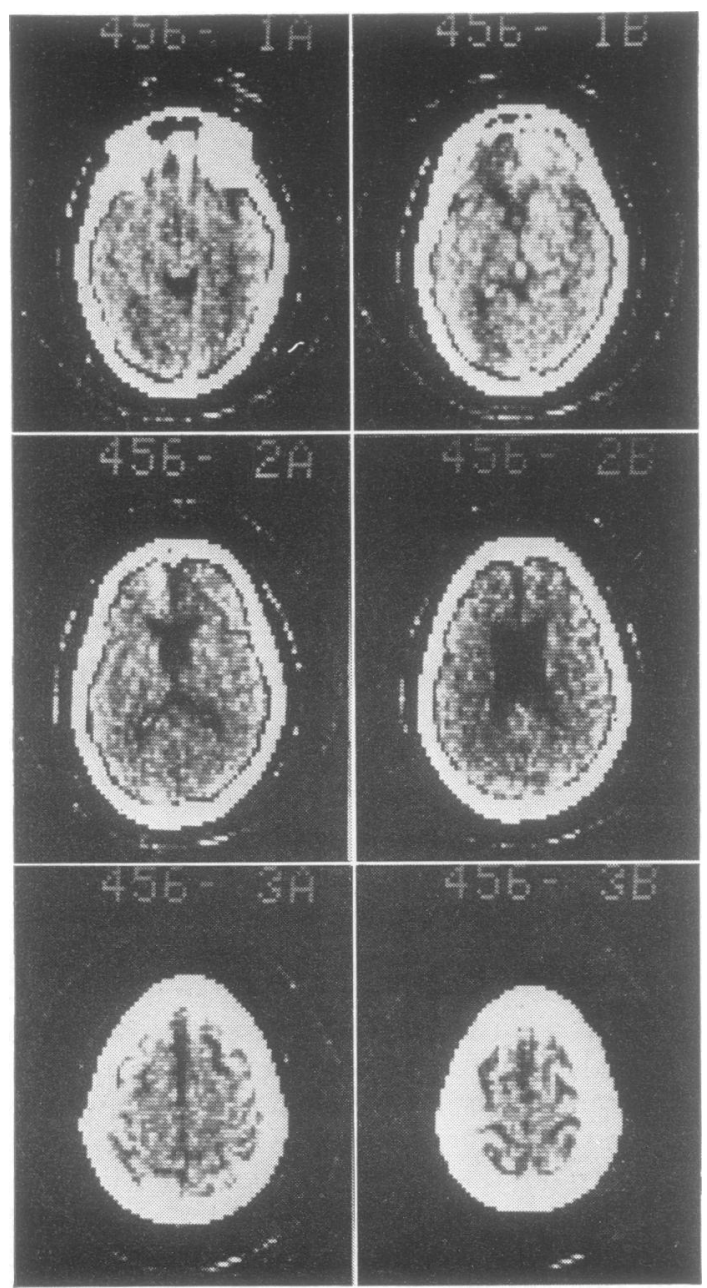

FIG. 5 Cerebral atrophy. 80 by 80 matrix.
TABLE 2

COMPARISON OF EMI SCAN AND VENTRICULAR CONTRAST PROCEDURE (78 PATIENTS)

\begin{tabular}{lll}
\hline $\begin{array}{l}\text { Different findings between techniques } \\
\text { (19 patients) }\end{array}$ & No. & $\begin{array}{c}\text { Total } \\
n o .\end{array}$ \\
\hline $\begin{array}{l}\text { Ventricular contrast procedure inadequate } \\
\text { a. EMI scan normal } \\
\text { b. EMI scan cerebral atrophy }\end{array}$ & 5 & \\
\hline Total & 2 & \\
\hline $\begin{array}{l}\text { EMI scan normal } \\
\text { a. AEG third ventricle ballooned } \\
\text { b. AEG lateral ventricles dilated } \\
\text { c. AEG cortical sulci enlarged }\end{array}$ & 7 & 7 \\
\hline $\begin{array}{l}\text { Total } \\
\text { Ventricular dilatation on both studies } \\
\text { a. Enlarged sulci seen on EMI scan only }\end{array}$ & 2 & \\
b. Enlarged sulci seen on AEG only & 3 & \\
\hline Total & 6 & 6 \\
\hline
\end{tabular}

the ventricular system on both studies but widening of the cortical sulci was seen only on the scan in three and only on the pneumoencephalogram in three. Enlarged sulci were missed on the contrast procedure because they failed to fill with air and on the EMI scan because tomograms were not obtained at the appropriate level.

The lateral, third, and fourth ventricles could always be identified on EMI scans when technically adequate tomograms had been obtained at appropriate levels. The temporal horns of the lateral ventricles however, were seen on the EMI scan only when they were enlarged. Clear demonstration of the cortical sulci on the scan implied that they were dilated (Fig. 5). Widening of the interhemispheric fissure and deepening of the subarachnoid space overlying the island of Reil (circular cistern) were helpful signs of cerebral atrophy on computerized scans. Undoubted widening of the interhemispheric fissure was present in 10 and enlargement of the insular cistern in 15 of the 33 patients of this series with definite cerebral atrophy.

Enlargement of cerebellar sulci was present in 17 of the patients with cerebral atrophy. This was detected by both investigations in 13 , by pneumoencephalography alone in two, and by EMI scan alone in two. When cerebellar atrophy 


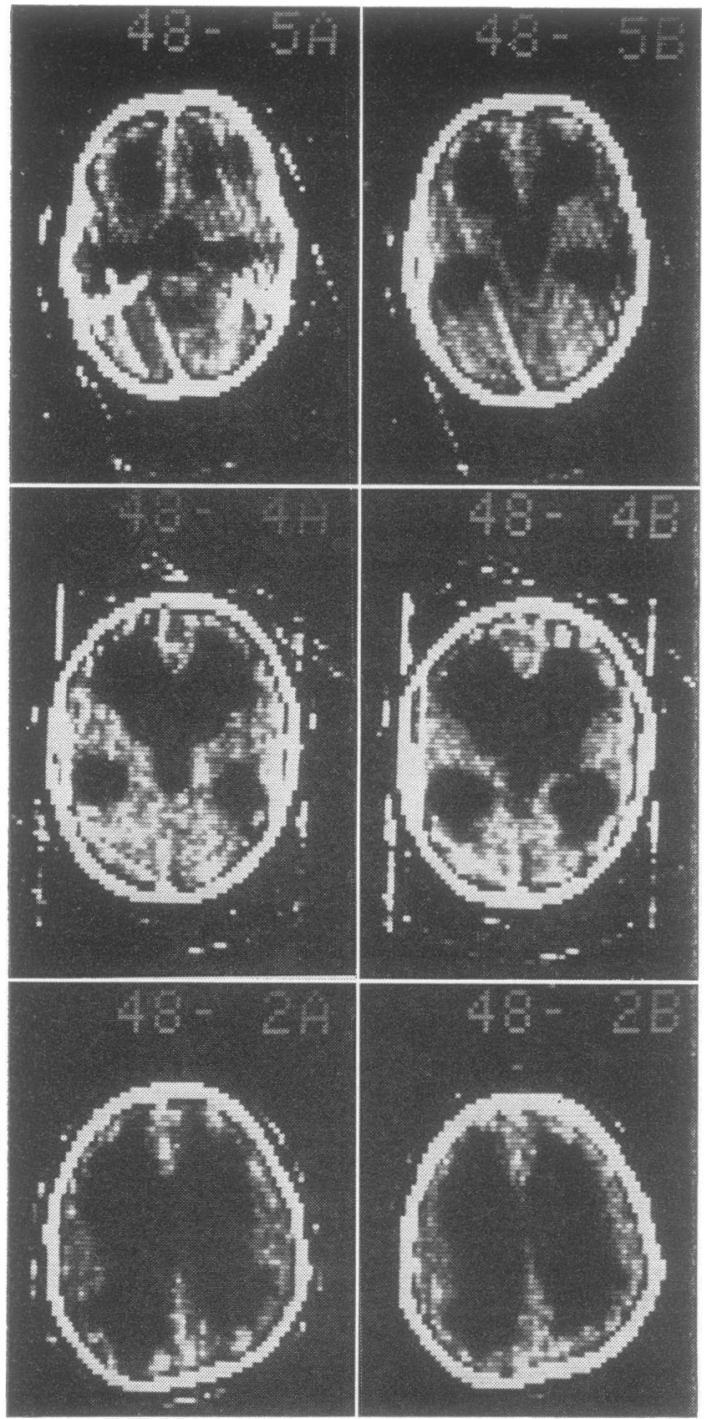

(a)

was present, the cisterns surrounding the brain stem, especially the ambient cisterns, were often strikingly prominent on the EMI scan.

Ventricular measurements have been selected from those in which both studies were unequivocally normal, showed cerebral atrophy or hydrocephalus. Directly comparable dimensions from the two studies are given in tabular form for each of these groups (Tables 3-5).

In all three groups, the ventricular parameters measured directly on the EMI scan were on

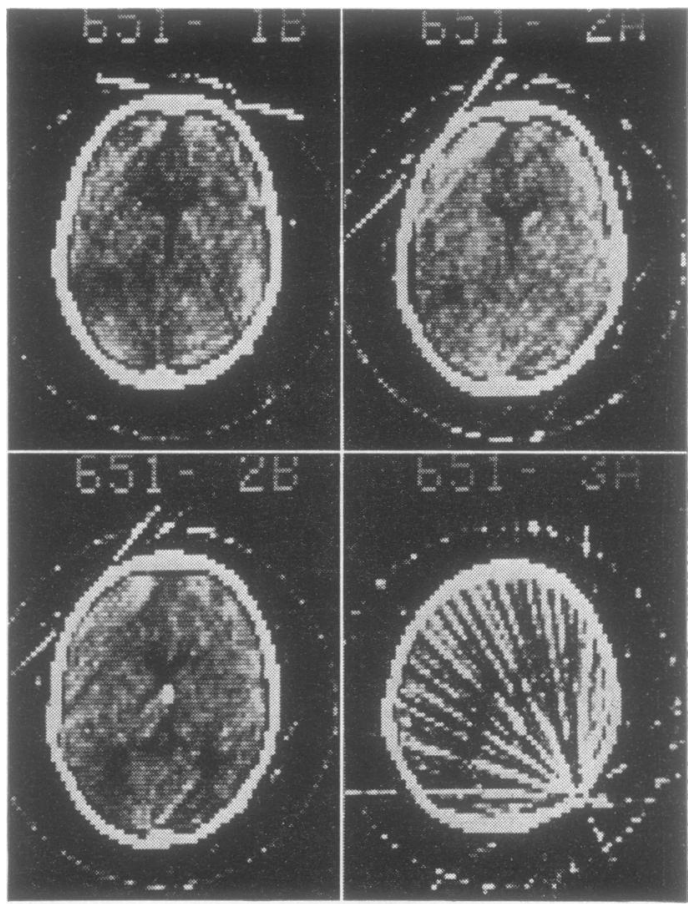

(b)

FIG. 6 (a, left; b, above) (a) Hydrocephalus due to aqueduct stenosis. 80 by 80 matrix. (b) After the insertion of a shunt there has been a dramatic reduction in ventricular size. The radial artefact seen on 'slice' $3 A$ is due to the metal component of a Holter valve; such aberrations have been almost eliminated by the 160 by 160 system.

average less than the equivalent dimensions on the contrast procedures. Among normal subjects, the mean value for Evans's ratio was also less on the scan. In those with cerebral atrophy or hydrocephalus, however, Evans's ratio was on average slightly greater on the EMI scan.

The temporal horn of the lateral ventricle was seen on the EMI scan only when its lateral cleft was $6 \mathrm{~mm}$ or more in height on the contrast study (measurement F). Similarly, cortical sulci were visible on the scan when they measured 


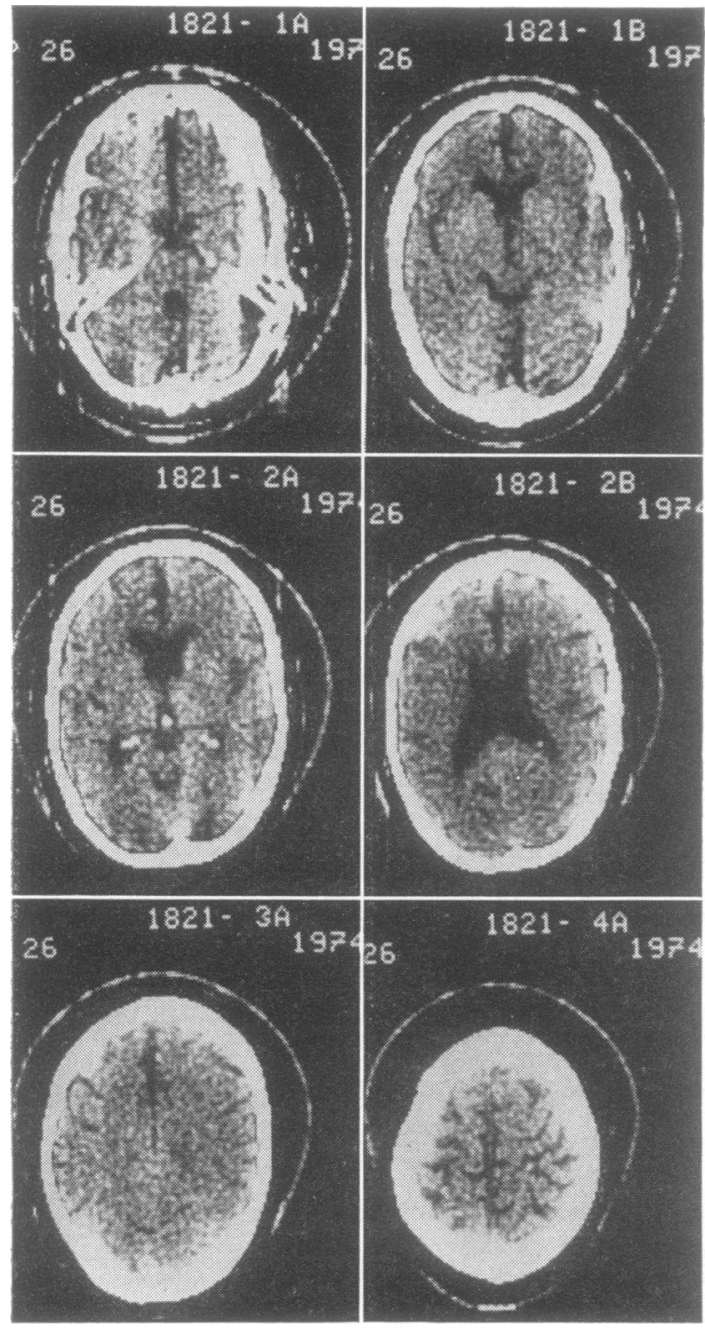

FIG. 7 Cerebral atrophy. 160 by 160 matrix.

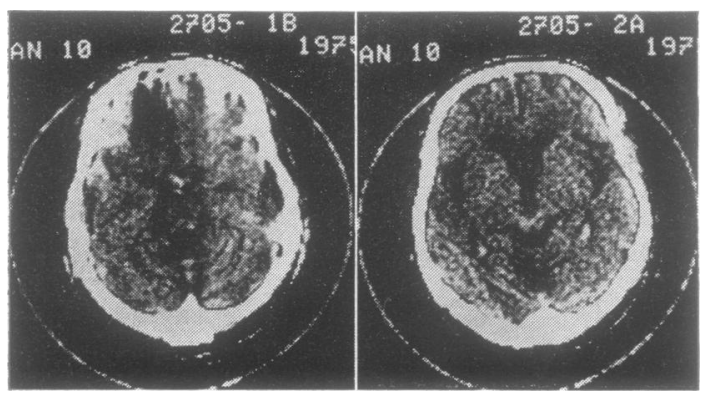

FIG. 8 Cerebellar atrophy. 160 by 160 matrix.
TABLE 3

COMPARISON OF VENTRICULAR DIMENSIONS (11 NORMAL SUBJECTS)

\begin{tabular}{|c|c|c|c|c|}
\hline & \multicolumn{2}{|c|}{ Range } & \multicolumn{2}{|c|}{ Mean } \\
\hline & $\begin{array}{l}E M I \\
\text { scan } \\
(\mathrm{mm})\end{array}$ & $\begin{array}{c}\text { Contrast } \\
\text { study } \\
(\mathrm{mm})\end{array}$ & $\begin{array}{l}\text { EMI } \\
\text { scan } \\
(\mathrm{mm})\end{array}$ & $\begin{array}{c}\text { Contrast } \\
\text { study } \\
(\mathrm{mm})\end{array}$ \\
\hline $\begin{array}{l}\text { A. Width of cellae mediae } \\
\text { B. Width to tips of frontal }\end{array}$ & $24-39$ & $28-41$ & 33.0 & 35.5 \\
\hline horns & $21-36$ & $32-50$ & 29.7 & 40.5 \\
\hline $\begin{array}{l}\text { C. Width of third ventricle } \\
\text { D. Height of fourth }\end{array}$ & $3-6$ & $3-9$ & 4.6 & 5.6 \\
\hline $\begin{array}{l}\text { ventricle } \\
\text { Evans's ratio }\end{array}$ & $\begin{array}{c}6-15 \\
0.18-0.30\end{array}$ & $\begin{array}{c}10-18 \\
0.23-0.30\end{array}$ & $\begin{array}{c}10.8 \\
0.24\end{array}$ & $\begin{array}{c}15.8 \\
0.27\end{array}$ \\
\hline
\end{tabular}

TABLE 4

COMPARISON OF VENTRICULAR DIMENSIONS (20 SUBJECTS WITH CEREBRAL ATROPHY)

\begin{tabular}{|c|c|c|c|c|}
\hline & \multicolumn{2}{|c|}{ Range } & \multicolumn{2}{|c|}{ Mean } \\
\hline & $\begin{array}{l}E M I \\
\text { scan } \\
(\mathrm{mm})\end{array}$ & $\begin{array}{c}\text { Contrast } \\
\text { study } \\
(\mathrm{mm})\end{array}$ & $\begin{array}{l}E M I \\
\text { scan } \\
(\mathrm{mm})\end{array}$ & $\begin{array}{c}\text { Contrast } \\
\text { study } \\
(\mathrm{mm})\end{array}$ \\
\hline $\begin{array}{l}\text { A. Width of cellae mediae } \\
\text { B. Width to tips of frontal }\end{array}$ & $27-45$ & $40-64$ & 38.6 & 48.3 \\
\hline horns & $33-60$ & $40-65$ & 43.1 & 53.4 \\
\hline $\begin{array}{l}\text { C. Width to third ventricle } \\
\text { D. Height of fourth }\end{array}$ & $6-15$ & $5-22$ & 9.0 & 10.2 \\
\hline $\begin{array}{l}\text { ventricle } \\
\text { Evans's ratio }\end{array}$ & $\begin{array}{c}9-24 \\
0.27-0.44\end{array}$ & $\begin{array}{c}14-25 \\
0.29-0.41\end{array}$ & $\begin{array}{c}12.0 \\
0.34\end{array}$ & $\begin{array}{c}18.4 \\
0.33\end{array}$ \\
\hline
\end{tabular}

TABLE 5

COMPARISON OF VENTRICULAR DIMENSIONS (12 SUBJECTS WITH HYDROCEPHALUS)

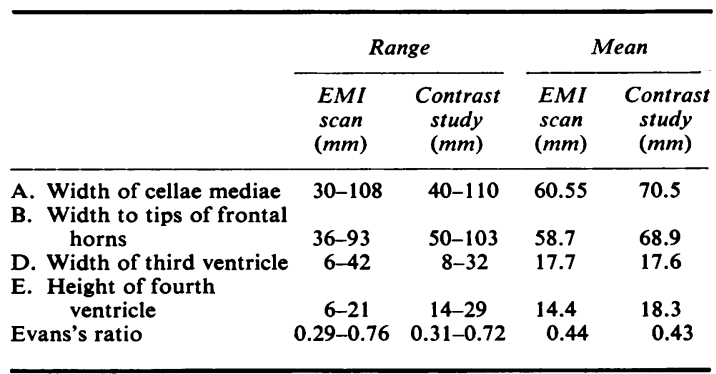

$4 \mathrm{~mm}$ or more in width on the contrast procedure.

Several hydrocephalic patients were subsequently managed by ventricular shunting operations and serial computerized scans thereafter have proved of value in monitoring progress 
(Fig. 6). A number of cases from this series have been re-examined using the high definition 160 by 160 matrix and a significant improvement in resolution was apparent (Figs 7 and 8).

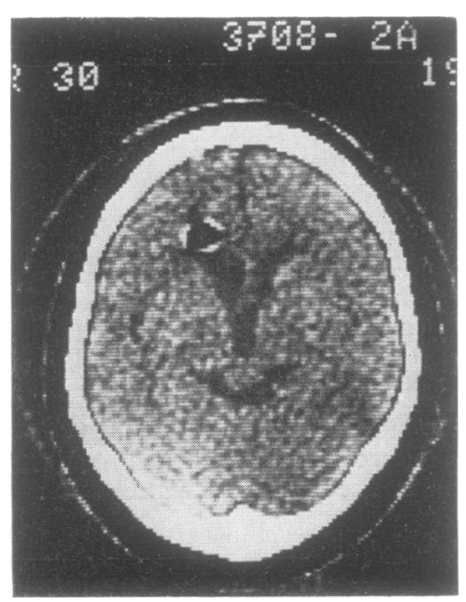

FIG. 9 EMI scan of a patient whose ventricular system contains some air after encephalography. The right frontal horn which contains the air appears distended.

Several patients, not included in this series, have undergone computerized scanning while residual air, usually from encephalography, was present in the ventricles. An illustration of such a case has been included (Fig. 9) to show that the segment of ventricle containing air may be locally expanded.

\section{DISCUSSION}

The diagnosis of cerebral or cerebellar atrophy can be made from the EMI scan with the same degree of accuracy as pneumoencephalography. When searching for evidence of cortical atrophy on computerized tomograms it is essential to obtain appropriate 'slices' toward the skull vertex and, likewise, adequate 'slices' incorporating the superior cerebellar vermis are needed to disclose cerebellar atrophy.

Hydrocephalus is also reliably detected but certain disadvantages should be noted in this context. Pneumoencephalography allows the passage of contrast medium to be followed along the cerebrospinal fluid containing pathways and the level of obstructive lesions may be so determined. Computerized tomography yields a static record and, when the entire ventricular system is dilated, the level of obstruction may not be apparent. An EMI scan alone, for example, could not distinguish hydrocephalus due to atresia of the exit foramina of the fourth ventricle from basal cistern block. When the scan shows only diffuse ventricular enlargement, in the absence of cortical atrophy, a contrast procedure-pneumoencephalography, ventriculography, or RIHSA encephalography depending on the clinical circumstances-will be required.

Two patients in this series showed ballooning of the anterior recesses of the third ventricle on pneumoencephalography, although ventricular size was otherwise normal. Both patients, one with a small acoustic neuroma and the other with cerebellar ectopia, had normal EMI scans. In this context, the continued need for contrast procedures in those where the clinical suspicion of a posterior fossa or perisellar lesion is strong but the EMI scan negative, must be emphasized.

Measurements taken directly from the EMI scan printout were all somewhat smaller than the equivalent dimensions taken from contrast procedures. There are three possible explanations. First, the ventricles may be magnified by conventional radiographs; second, the ventricular system may be inflated by the introduction of air (Probst, 1973); and, third, ventricular size may be underestimated by computerized tomography.

Evans's ratio eliminates the problem of magnification, and in normal subjects the lateral ventricles still appeared smaller on EMI scans. Returning to the consideration of ventricular measurement based on the cell size of computerized tomograms, it is likely that narrow segments of the ventricular system will be underestimated as their extremities would be lost in cells containing principally cerebral tissue. This conclusion is supported by the greater discrepancy in size on measuring the tips of the frontal horns on the one hand and the less marked discrepancy between measurements of the cellae mediae on the other.

Inflation of the ventricular system by air would also seem likely in normal subjects, for 
computerized scans showing air in the ventricles often illustrate expansion of the segments containing gas.

Among patients with either hydrocephalus or cerebral atrophy, Evans's ratio was, on average, a little larger from the EMI scan than from the contrast procedure, the reverse of the situation in normal subjects. Analysis of individual cases showed that, in some patients with a markedly dilated ventricular system, the lateral ventricles were larger when measured on the EMI scan. This suggests that either ventricular inflation after the introduction of air is less marked when the ventricles are dilated or that contrast procedures in some of these cases actually deflate the ventricular system. While deflation might be expected in those with obstructive hydrocephalus, it is surprising that it also appears to occur in some patients with cerebral atrophy.

Bearing in mind the limitations of measurement on EMI scans and noting the apparent reduction in ventricular size seen in normal subjects when scans are compared with contrast procedures, a normal range of ventricular

TABLE 6

MEASUREMENTS FROM EMI SCAN

\begin{tabular}{|c|c|c|c|}
\hline & $\begin{array}{c}\text { Normal } \\
(\mathrm{mm})\end{array}$ & $\begin{array}{l}\text { Borderline } \\
(\mathrm{mm})\end{array}$ & $\begin{array}{c}\text { Enlarged } \\
(\mathrm{mm})\end{array}$ \\
\hline $\begin{array}{l}\text { A. Width of cellae mediae } \\
\text { B. Width to tips of frontal } \\
\text { horns } \\
\text { C. Width at midpoint of } \\
\text { frontal horns } \\
\text { D. Width of third ventricle } \\
\text { E. Height of fourth ventricle } \\
\text { Evans's ratio }\end{array}$ & $\begin{array}{l}36 \text { or less } \\
39 \text { or less } \\
18 \text { or less } \\
6 \text { or less } \\
12 \text { or less } \\
0.29 \text { or less }\end{array}$ & $\begin{array}{c}21 \\
9 \\
15 \\
0.30\end{array}$ & $\begin{array}{l}24 \\
12 \\
18 \\
0.31\end{array}$ \\
\hline
\end{tabular}

parameters for the EMI scan is suggested (Table 6).

The EMI scan is a harmless, painfree method of diagnosing cerebral atrophy or hydrocephalus which removes the need for conventional contrast procedures in many cases. Scanning may be undertaken to provide a firm diagnosis among patients in whom contrast procedures are not justified and, because the exposure to $x$-rays is low, serial examination is also feasible. The technique is therefore ideal for monitoring the progress of disease or the effects of treatment and for screening those, such as the survivors of subarachnoid haemorrhage, who run the risk of developing hydrocephalus. The EMI scan is performed under physiological conditions, so that artefacts which might result from anaesthesia or contrast substances are avoided and the identification of fluid-containing structures does not depend upon their adequate filling by contrast media. As computerized tomography becomes more sophisticated, it would seem likely that the indications for conventional ventricular contrast procedures will decline still further.

We should like to thank EMI Limited for their support of our research programme. Invaluable radiographic assistance was provided by Miss V. Fullom, secretarial assistance by Miss S. Andrews, and photographic help by Mr H. Prentice.

\section{REFERENCES}

Evans, W. A. (1942). An encephalographic ratio for estimating ventricular enlargement and cerebral atrophy. Archives of Neurology and Psychiatry, 47, 931-937.

Engeset, A., and Skraastad, E. (1964). Methods of measurement in encephalography. Neurology (Minneap.), 14, 381-385.

Probst, F. P. (1973). Gas distension of the lateral ventricles at encephalography. Acta Radiologica, Diagnosis, 14, 1-4. 